\title{
The Studies of Effect of Bio Fertilizers Rhizobium, Phosphobacteria, and Root Nodule Extract (R.PB, R+PB \& RNE) on the Growth and Certain Biochemical Changes in the Seedlings of Black Gram \& Maize
}

Rekha Gomathinayagam ${ }^{1}$, Gomathinayagam Subramanian ${ }^{2 *}$, Mahendra Persaud ${ }^{3}$, Rajendar Persaud $^{3} \&$ Shanmugaiha Velusamy ${ }^{1}$

${ }^{I}$ Department of Microbial Technology, School of Biological Science, Madurai Kamarj University, Madurai, Tamil Nadu, India.

${ }^{2}$ Faculty of Agriculture and Forestry, University of Guyana Berbice Campus, Tain, Guyana.

${ }^{3}$ Department of Plant Pathology, Burma Rice Research Station, Guyana Rice Development of Board, Guyana.

Copyright: () 2021 Rekha Gomathinayagam et al. This is an open access article distributed under the terms of the Creative Commons Attribution License, which permits unrestricted use, distribution, and reproduction in any medium, provided the original author and source are credited.

\section{ABSTRACT}

A pot culture experiment was carried out and to the find out the effect of Rhizobium, Phosphobacteria and Root Nodule extract on the vegetative growth and biochemical changes in Black gram and Maize. The Black gram and Maize is vegetative parameters such as seed germination, shoot and root length, leaf fresh weight, leafs dry weight, shoot and root dry weight had analyzed and biochemical studies of both Black gram and Maize was carried such as total chlorophyll content, leave soluble protein and in vivo nitrate reductase activity. Among microbial inoculants, the Rhizobium + PB mixer was found most effective in terms of seed germination, shoot and root length, leaf fresh weight, leafs dry weight, shoot and root dry weigh and also showed increase total chlorophyll content, soluble protein and nitrate activities in both Black gram and Maize.

Keywords: Black gram, Maize, Rhizobium, Phosphobacteria, Root nodule, Bio-fertilizer.

\section{Introduction}

Bio-fertilizers are very cheap and renewable source of plant nutrients as they are living organisms. Though the use of Rhizobium Culture for leguminous crop is known for long the field application of Azotabacter, Azospirillum, Rhizobium and Phosphobacteria etc. bio fertilizers form excellent supplementary manure for various cultivated crops as well as substitute. Pulses are cultivated in India in as area of 24 million hectares annually. The grains form the major source of protein for those who are no accustomed to non-vegetarian diet. The per capita consumption of pulses at all Indian level is 35 at present which was 75g in 1960-61. Hence efforts are being made to increase the pulses production. Phosphobacteria (Phosphate Solubilizing Bacteria) one of the bio-fertilizer and it is mainly used in the cereals crops. Phosphobacteria also enhances of the plant growth and biochemical level. Phosphobacteria now day widely used for the agricultural purposes.

Black gram is one of the important pulse crops grown throughout of India. It is grown almost entirely as a dry crop in tracts with a rainfall not exceeding about 35" in the tracts of heavier rainfall it is raised only in the season following the cessation of the rain. Black gram is grown in two seasons, as an early or midseason crop it is sown in the early part of May, as a midseason crop is shown in June or July as a late crop in the month of October.

Maize, also called Indian corn (or merely "CORN" in the U.S.A.) is a food grain of considerable importance in many parts of the world, notably in North, Central and South America. To an even greater extent the grain is used as food for all kinds of farm animals, while the plant themselves furnish large quantities of succulent green fodder and are grown almost as much for their value as green fodder and silage as for the grain. The crop said to be a native of Central America and Mexico from where it has spread to other parts of the world. 
In the present studies as attempt has been made to know the effect of biofertilizers ( $R$. PB, R+PB \& RNE) on the growth and certain biochemical changes in the seedlings of Black grown \& maize. The growth parameters such as root length, shoot length, root fresh weight, dry weight, shoot fresh weight and dry weight were studied. The biochemical parameters such as total chlorophyll content soluble protein content and NRA activity as studied.

\section{Materials and Methods}

The effect of bio fertilizers (R, PB, R+PB and RNE) on the growth and certain bio chemical changes were studied on the Black gram and Maize. The Black gram variety $\mathrm{Co} 5$ and maize $\mathrm{Co} 2$ were procured from Agricultural Research Centre, Kovilpatti, Tamil Nadu, India. In this study the bio fertilizers were inoculated through the Nutrient medium.

\section{Preparation of Nutrient Medium}

The nutrient solution was prepared by mixing major \& minor Nutrient solution by standard methods. This nutrient solution was treated with bio fertilizer of $\mathrm{R}, \mathrm{PB} . \mathrm{R}+\mathrm{PB}$ mixture and $\mathrm{RNE}$ in separate containers.

\section{Inoculation of Bio-fertilizers}

The bio-fertilizer were treated in the Nutrient Solution by dissolving $5 \mathrm{gm}$ of R, PB, mixture of R+PB (2.5 gm each) root nodules extract in separate containers.

\section{Root Nodule Extract}

Root nodules were selected \& harvested freshly from leguminous plant (Teprosia purpuriea) and it was thoroughly cleaned/washed in distilled water. $5 \mathrm{gm}$ of fresh nodules were ground in $5 \mathrm{ml}$ of sterile water. This was used as root nodules extract. This extract was treated with nutrient solution.

The above prepared bio fertilizes inoculated Nutrient solutions were used for our study. Control was made by using nutrient solution without mixing bio fertilizers.

\section{Cultivation of plants}

Soil was thoroughly washed in the water for two to three times for the removal of unwanted seeds, spores and other materials. The washed soil was dried in the Sun light for two days. The dried Soil was again sterilized in the hot air oven at $160^{\circ} \mathrm{C}$ for 2 hours. The sterilized soil was used for raising of plants. The sterilized soil was taken in the earthen pot. The seeds of Black gram and maize were soaked in the water for $2 \mathrm{hrs}$. Later the seeds were planted in earthen pot separately (maize and black gram).

\section{Percentage of Germination}

Healthy and uniform sized deeds of black gram and maize were soaked in the nutrient solution of $\mathrm{R}, \mathrm{PB}, \mathrm{R}+\mathrm{PB}$ mixture and RNE for 24 hours in a Petridis (20 seeds per plate) lined with sterilized cotton.

Enough amount of the above nutrient solutions was added to the Petridis and the control was made by using nutrient solution (without bio fertilizer) only on 3rf day; the percentage of seed germination was calculated by using of following formula. 


\section{Percentage of seed germination}

Percentage of seed germination $=\frac{\% \text { No of seed germinated }}{\text { No of seed sown }} \times 100$

\section{Shoot and Root Length}

The intact seedling of both control and treated planted were harvested (without damage) on $7^{\text {th }}$ day, $14^{\text {th }}, 21^{\text {st }}$ and $28^{\text {th }}$ day the shoot length root length, was measured in $\mathrm{cm}$.

\section{Fresh Weight in Shoot and Root}

The intact seedling of both control and treated planted were harvested (without damage) on $7^{\text {th }}$ day, $14^{\text {th }}, 21^{\text {st }}$ and $28^{\text {th }}$ day the shoot length root length, was measured in mgs.

\section{Dry Weight in Shoot and Root}

The intact seedling of both control and treated planted were harvested (without damage) on $7^{\text {th }}$ day, $14^{\text {th }}, 21^{\text {st }}$ and $28^{\text {th }}$ day and the dry weight of root and shoot was measured after drying in the shoot and root in the oven at $120^{\circ} \mathrm{c}$ for 24 hours.

\section{Biochemical Analysis}

\section{(1) Total Chlorophyll (ARNON'S 1949)}

Total chlorophyll analysis was used Aron's methods.

Chlorophyll content is calculated by using the following Aron's (1949) formula.

Chlorophyll a mg lit $=12.7 \times$ A663 $-2.69 \times$ a645 x

Chlorophyll b mg lit 22.9 x A645 V/W x 100

$4.68 \times \mathrm{A} 663 \times \mathrm{V} / \mathrm{W} \times 100$

Total Chlorophyll mg/lit $=20.8 \times$ A645 $+80.2 \times$ A663

$\mathrm{x} \mathrm{V/W}$ x 100

$\mathrm{V}-$ Volume of the extract \& $\mathrm{W}-$ Weight of the leaf materials

\section{(2) Leaf Soluble Protein (LOWRY'S METHOD 1951)}

The soluble protein was analyzed by Lowry's methods.

The amount of protein was estimated by using a standard graph.

\section{(3) In Vivo Nitrate Reductase Enzyme (n.r.e.c.1.6.6.1) activity (JAWORSKI 1971)}

$100 \mathrm{ml}$ of leaf bits were prepared from the control and treated plant and it was place in a vival containing $5 \mathrm{ml}$ of incubation medium (assay medium PH 7.5). Incubation was carried out in dark for $1 / 2$ hour at room temperature in ice cold condition with by giving frequent shaking. After $1 / 2$ hour, $0.5 \mathrm{ml}$ of assay medium was taken and it was 
added with $1.5 \mathrm{ml}$ distilled water and $1 \mathrm{ml}$ of sulphanilamide, $1 \mathrm{ml}$ of $\mathrm{N}-1-\mathrm{N}$ (1 - Napthyl ethylene diamine hydrochloride. It was allowed to keep in an undisturbed condition for 10 minutes for the development of blue color. After 10 minutes the solution was subjected for taking OD at $540 \mathrm{~nm}$ by using proper blank solution. $2 \mathrm{ml}$ of distilled water, $1 \mathrm{ml}$ sulphanilamide, and $1 \mathrm{ml} \mathrm{N}-1-\mathrm{N}$.

The NR activity was calculated by finding the nitrate content of the incubated assay medium. The Nitrate content was directly proposanal to the activation of enzyme (NRA) related by which nitrate is converted to nitrate.

\section{Results}

The effect of bio fertilizer on the growth and certain biochemical changes were studied in black gram and maize. The results were as follows:

\section{Germination Percentage}

The germination percentage was increase in all the treated condition in both black gram and maize when compare with control. It was noted that only $5 \%$ was increased in $\mathrm{R}+\mathrm{P}$ mixture were as in $\mathrm{R}, \mathrm{PB}, \mathrm{RNE}$ treated condition $12 \%$ was increased than the control there was no significant difference observed among maize and black gram (Table 1).

Table 1. Germination in Percentage

\begin{tabular}{|c|c|c|c|}
\hline S. No. & Treatment & Black gram in \% & Maize in \% \\
\hline 1. & C & 100 & 100 \\
\hline 2. & R & 112 & 112 \\
\hline 3. & PB & 112 & 112 \\
\hline 4. & R+PB mix & 105 & 105 \\
\hline 5. & RNE & 112 & 112 \\
\hline
\end{tabular}

\section{Shoot Fresh Weight}

The fresh weights of the shoot were noted on $7^{\text {th }}$ day $14^{\text {th }}, 21^{\text {st }}$, and $28^{\text {th }}$ day. There was no significant levels of fresh weight were noted on the above date of harvest but it was gradually increased. However the fresh weight on $28^{\text {th }}$ day analysis were $300,324,306.60,304 \& 305 \mathrm{mgs}$ from the control and treated plant of R,PB, R+PB mixture and RNE (respectively) in black gram and 830,910.90,868.40,847 \&856.00 mgs from the control and treated plant of $\mathrm{P}, \mathrm{PB}, \mathrm{R}+\mathrm{PB}$ and RNE (respectively) in maize (Table 2).

Table 2. Shoot Fresh Weight in mg

\begin{tabular}{|c|c|c|c|c|c|c|c|c|c|}
\hline \multicolumn{2}{|c|}{} & \multicolumn{2}{|c|}{${7^{\text {th }}}^{2}$ Day } & \multicolumn{2}{c|}{$\mathbf{1 4}^{\text {th }}$ Day } & \multicolumn{2}{c|}{$2^{\text {st }}$ Day } & \multicolumn{2}{c|}{$\mathbf{2 8}^{\text {th }}$ Day } \\
\hline S. No. & Treatment & B & M & B & M & B & M & B & M \\
\hline 1. & C & 270.80 & 800 & 280.80 & 806.00 & 290.30 & 826.10 & 300.00 & 830.00 \\
\hline & & $100 \%$ & $100 \%$ & $100 \%$ & $100 \%$ & $100 \%$ & $100 \%$ & $100 \%$ & $100 \%$ \\
\hline 2. & R & 310.00 & 847 & 313.50 & 861.40 & 323.80 & 871.20 & 324.20 & 910.09 \\
\hline
\end{tabular}


Asian Journal of Applied Science and Technology (AJAST)

Volume 5, Issue 4, Pages 01-15, Oct-Dec 2021

\begin{tabular}{|c|c|c|c|c|c|c|c|c|c|}
\hline & & $114 \%$ & $106 \%$ & $112 \%$ & $107 \%$ & $112 \%$ & $105 \%$ & $108 \%$ & $110 \%$ \\
\hline 3. & PB & 290.60 & 830 & 296.60 & 840.00 & 299.80 & 850.20 & 306.60 & 868.40 \\
\hline & & $107 \%$ & $104 \%$ & $106 \%$ & $104 \%$ & $103 \%$ & $103 \%$ & $102 \%$ & $105 \%$ \\
\hline 4. & R+PB mix & 279.40 & 810 & 284.00 & 815.00 & 294.00 & 835.20 & 304.00 & 847.00 \\
\hline & & $103 \%$ & $101 \%$ & $101 \%$ & $101 \%$ & $101 \%$ & $101 \%$ & $101 \%$ & $102 \%$ \\
\hline 5. & RNE & 280.90 & 812 & 288.80 & 819.00 & 298.80 & 849.50 & 305.00 & 856.00 \\
\hline & & $104 \%$ & $102 \%$ & $103 \%$ & $102 \%$ & $103 \%$ & $103 \%$ & $102 \%$ & $103 \%$ \\
\hline
\end{tabular}

\section{Note; $B=$ Black gram, $M=$ Maize}

This result showed that the fresh weight of the shoot from all the treated plant was increased than that of control in both black gram and maize. The fresh weights were moderately increased in all the treated condition ranges from in $1 \%$ to $8 \%$ in black gram and $2 \%$ to $10 \%$ in maize. It was also noted that the fresh weight of the maize was higher that of black gram.

\section{Root Fresh Weight}

The fresh weights of the root were noted on $7^{\text {th }}$ day $14^{\text {th }}, 21^{\text {st }}$ and $28^{\text {th }}$ day. There was no significant levels of fresh weight were noted on the above date of harvest but it was gradually increased. However the fresh weight of root on $28^{\text {th }}$ day analysis were $109.00,157.00,136.70,128.60 \mathrm{mg}$ from the control and treated plants of $\mathrm{P}, \mathrm{PB}, \mathrm{R}+\mathrm{PB}$ mixture and RNE (respectively) in black gram and 172.00, 280.00, 222.30, 201.80, 208.20 mgs from the control and the treated plants of $\mathrm{P}, \mathrm{PB}, \mathrm{R}+\mathrm{PB}$ mixture and RNE (respectively) in maize (Table 3).

Table 3. Root Fresh Weight in mg

\begin{tabular}{|c|c|c|c|c|c|c|c|c|c|}
\hline \multicolumn{2}{|l|}{} & \multicolumn{2}{|c|}{$7^{\text {th }}$ Day } & \multicolumn{2}{c|}{$1^{\text {th }}$ Day } & \multicolumn{2}{c|}{$\mathbf{2 1}^{\text {st }}$ Day } & \multicolumn{2}{c|}{$\mathbf{8}^{\text {th }}$ Day } \\
\hline S. No. & Treatment & B & M & B & M & B & M & B & M \\
\hline 1. & C & 99.90 & 149 & 101.00 & 152.00 & 108.70 & 162.00 & 109.00 & 172.00 \\
\hline & & $100 \%$ & $100 \%$ & $100 \%$ & $100 \%$ & $100 \%$ & $100 \%$ & $100 \%$ & $100 \%$ \\
\hline 2. & R & 113.30 & 250 & 123.60 & 267.30 & 133.70 & 272.30 & 157.60 & 280.00 \\
\hline & & $113 \%$ & $168 \%$ & $122 \%$ & $176 \%$ & $124 \%$ & $168 \%$ & $145 \%$ & $163 \%$ \\
\hline 3. & PB & 102.94 & 180.5 & 116.34 & 195.30 & 128.38 & 205.30 & 136.70 & 222.30 \\
\hline 4. & R+PB mix & 101.70 & 158 & 110.00 & 162.00 & 115.60 & 172.00 & 120.60 & 201.80 \\
\hline & & $102 \%$ & $106 \%$ & $110 \%$ & $107 \%$ & $107 \%$ & $106 \%$ & $110 \%$ & $117 \%$ \\
\hline 5. & RNE & 104.12 & 174 & 112.14 & 184.00 & 118.50 & 194.50 & 128.60 & 208.20 \\
\hline & & $109 \%$ & $117 \%$ & $111 \%$ & $121 \%$ & $110 \%$ & $120 \%$ & $118 \%$ & $121 \%$ \\
\hline
\end{tabular}

Note; $B=$ Black gram, $M=$ Maize 
This result showed that, the fresh weight of root from all the treated plant was increase than that of control in both black gram and maize. The fresh weights were moderately increased in all the treated condition ranges from $10 \%$ to $45 \%$ in black gram and $10 \%$ to $63 \%$ in maize. It was also noted that the fresh weight of maize was higher than that of black gram.

\section{Shoot Dry Weight}

The dry weights of the shoot were noted on $7^{\text {th }}$ day $14^{\text {th }}, 21^{\text {st }}$ and $28^{\text {th }}$ day. The dry weight was gradually increased in the above date of harvest. However the dry weight on $28^{\text {th }}$ day analysis were $28.10,39.00,29.26,32.14 \mathrm{mgs}$ from the control and treated plants P,PB,R+PB mixture and RNE (respectively) in black gram \& 72.19, 99.56, 99.99, $78.34 \& 86.64 \mathrm{mgs}$ from the control and treated plants of $\mathrm{P}, \mathrm{PB}, \mathrm{R}+\mathrm{PB}$ mixture and RNE (respectively) in maize (Table 4).

Table 4. Shoot Dry Weight in mg

\begin{tabular}{|c|c|c|c|c|c|c|c|c|c|}
\hline \multicolumn{2}{|l|}{} & \multicolumn{2}{|c|}{$7^{\text {th }}$ Day } & \multicolumn{2}{c|}{$1^{\text {th }}$ Day } & \multicolumn{2}{c|}{$\mathbf{2 1}^{\text {st }}$ Day } & \multicolumn{2}{c|}{$\mathbf{2 8}^{\text {th }}$ Day } \\
\hline S. No. & Treatment & B & M & B & M & B & M & B & M \\
\hline 1. & C & 20.24 & 65.68 & 22.24 & 69.04 & 25.30 & 70.08 & 28.10 & 72.19 \\
\hline & & $100 \%$ & $100 \%$ & $100 \%$ & $100 \%$ & $100 \%$ & $100 \%$ & $100 \%$ & $100 \%$ \\
\hline 2. & R & 32.05 & 79.00 & 34.04 & 84.00 & 37.64 & 86.08 & 39.00 & 99.56 \\
\hline & & $158 \%$ & $120 \%$ & $153 \%$ & $122 \%$ & $149 \%$ & $123 \%$ & $135 \%$ & $138 \%$ \\
\hline 3. & PB & 23.45 & 74.00 & 25.34 & 79.90 & 39.64 & 36.90 & 39.99 & 99.99 \\
\hline 4. & R+PB mix & 21.30 & 68.60 & 23.00 & 70.50 & 26.24 & 76.50 & 29.26 & 78.34 \\
\hline & & $116 \%$ & $113 \%$ & $114 \%$ & $116 \%$ & $157 \%$ & $124 \%$ & $138 \%$ & $139 \%$ \\
\hline 5. & RNE & 22.59 & 70.96 & 23.29 & 72.74 & 29.14 & 78.74 & 32.14 & 86.64 \\
\hline & & $112 \%$ & $108 \%$ & $105 \%$ & $105 \%$ & $115 \%$ & $112 \%$ & $111 \%$ & $120 \%$ \\
\hline
\end{tabular}

\section{Note; $B=$ Black gram, $M=$ Maize}

This result showed that the dry weight of the shoot from all the treated plants was increased than that of control in both black gram and maize. The dry weights were moderately increased in all the treated condition ranges from $1 \%$ to $38 \%$ in black gram and $9 \%$ to $30 \%$ in maize. It was also noted that the dry weight maize was higher than that of black gram.

\section{Root Dry Weight}

The dry weights of root were noted on $7^{\text {th }}$ day, $14^{\text {th }}, 21^{\text {st }}$ and $28^{\text {th }}$ day. The dry weight was gradually increased in the above date of harvest. However the dry weight on $28^{\text {th }}$ day analysis were $17.93,19.93,18.96,18.30$ and $19.29 \mathrm{mgs}$ 
from the control and treated plants of $\mathrm{P}, \mathrm{PB}, \mathrm{R}+\mathrm{PB}$ mixture and RNE (respectively) in black gram \& 31.64, 46.96, $48.74,32.96 \& 38.98 \mathrm{mg}$ from the control and treated plants of P,PB,R+PB and RNE (respectively) in maize (Table $5)$.

Table 5. Root Dry Weight in mg

\begin{tabular}{|c|c|c|c|c|c|c|c|c|c|}
\hline \multicolumn{2}{|c|}{} & \multicolumn{2}{|c|}{$7^{\text {th }}$ Day } & \multicolumn{2}{c|}{$1^{\text {th }}$ Day } & \multicolumn{2}{c|}{$\mathbf{2 1}^{\text {st }}$ Day } & \multicolumn{2}{c|}{$\mathbf{8 8}^{\text {th }}$ Day } \\
\hline S. No. & Treatment & B & M & B & M & B & M & B & M \\
\hline 1. & C & 15.00 & 20.65 & 15.80 & 23.45 & 16.96 & 27.45 & 17.93 & 31.64 \\
\hline & & $100 \%$ & $100 \%$ & $100 \%$ & $100 \%$ & $100 \%$ & $100 \%$ & $100 \%$ & $100 \%$ \\
\hline 2. & R & 16.88 & 35.50 & 17.88 & 38.86 & 18.96 & 42.86 & 19.98 & 46.96 \\
\hline & & $113 \%$ & $172 \%$ & $113 \%$ & $166 \%$ & $112 \%$ & $156 \%$ & $111 \%$ & $148 \%$ \\
\hline 3. & PB & 16.00 & 34.69 & 16.80 & 39.54 & 17.93 & 42.64 & 18.96 & 48.74 \\
\hline 4. & R+PB mix & 15.96 & 22.99 & 16.00 & 24.00 & 17.63 & 28.30 & 18.30 & 32.96 \\
\hline. & & $106 \%$ & $111 \%$ & $101 \%$ & $102 \%$ & $104 \%$ & $103 \%$ & $102 \%$ & $104 \%$ \\
\hline 5. & RNE & 16.40 & 29.89 & 17.80 & 30.62 & 18.99 & 34.69 & 19.29 & 38.98 \\
\hline & & $109 \%$ & $145 \%$ & $113 \%$ & $131 \%$ & $112 \%$ & $126 \%$ & $108 \%$ & $123 \%$ \\
\hline
\end{tabular}

\section{Note; $B=$ Black gram, $M=$ Maize}

This result showed that the dry weight of the shoot from all the treated plants was increased than that of control in both black gram and maize. The dry weights were moderately increased in all the treated condition ranges from $2 \%$ to $11 \%$ in black gram and $4 \%$ to $54 \%$ in maize. It was also noted that the dry weight maize was higher than that of black gram.

\section{Shoot Length}

The shoot lengths were noted on $7^{\text {th }}$ day, $14^{\text {th }}, 21^{\text {st }}$ and $28^{\text {th }}$ day. The shoot length was gradually increased in the above date of harvest. However, the shoot length on $28^{\text {th }}$ day analysis was $29.86,32.06,32.46,30.50 \& 31.04 \mathrm{~cm}$ from the control and treated plants of $\mathrm{P}, \mathrm{PB}, \mathrm{R}+\mathrm{PB}$ mixture and RNE (respectively) in black gram (plate -1) \& $34.20,38.30,37.60,35.40 \& 36.40 \mathrm{~cm}$ from the control and treated plants of P, PB, R+PB and RNE (respectively) in maize (Table 6).

Table 6. Shoot Length in $\mathrm{cm}$

\begin{tabular}{|c|c|c|c|c|c|c|c|c|c|}
\hline \multicolumn{2}{|c|}{} & \multicolumn{2}{|c|}{${7^{\text {th }}}^{2}$ Day } & \multicolumn{2}{c|}{$\mathbf{1 4}^{\text {th }}$ Day } & \multicolumn{2}{c|}{$\mathbf{2 1}^{\text {st }}$ Day } & \multicolumn{2}{c|}{$\mathbf{2 8}^{\text {th }}$ Day } \\
\hline S. No. & Treatment & B & M & B & M & B & M & B & M \\
\hline 1. & C & 20.35 & 30.84 & 23.84 & 31.64 & 29.63 & 32.63 & 29.86 & 34.20 \\
\hline & & $100 \%$ & $100 \%$ & $100 \%$ & $100 \%$ & $100 \%$ & $100 \%$ & $100 \%$ & $100 \%$ \\
\hline
\end{tabular}


Volume 5, Issue 4, Pages 01-15, Oct-Dec 2021

\begin{tabular}{|c|c|c|c|c|c|c|c|c|c|}
\hline 2. & $\mathrm{R}$ & 23.45 & 33.74 & 26.06 & 35.94 & 28.63 & 36.73 & 32.06 & 38.30 \\
\hline & & $115 \%$ & $109 \%$ & $109 \%$ & $114 \%$ & $116 \%$ & $113 \%$ & $107 \%$ & $112 \%$ \\
\hline 3. & PB & 22.63 & 32.64 & 25.02 & 34.76 & 27.53 & 34.83 & 32.46 & 37.60 \\
\hline & & $111 \%$ & $106 \%$ & $105 \%$ & $110 \%$ & $112 \%$ & $107 \%$ & $107 \%$ & $110 \%$ \\
\hline 4. & R+PB mix & 21.63 & 31.54 & 24.40 & 32.64 & 26.63 & 33.72 & 30.56 & 35.40 \\
\hline & & $106 \%$ & $102 \%$ & $102 \%$ & $107 \%$ & $108 \%$ & $103 \%$ & $102 \%$ & $104 \%$ \\
\hline 5. & RNE & 21.73 & 32.64 & 25.94 & 34.54 & 27.43 & 35.42 & 31.04 & 36.40 \\
\hline & & $107 \%$ & $106 \%$ & $109 \%$ & $109 \%$ & $111 \%$ & $110 \%$ & $104 \%$ & $106 \%$ \\
\hline
\end{tabular}

Note; $B=$ Black gram, $M=$ Maize

This result showed that the shoot length from all the treated plant was increases than that of control in both black gram and maize. In all the treated plants the shoot length were moderately increased from $2 \%$ to $7 \%$ in black gram and $4 \%$ to $12 \%$ in maize. It was also noted that the shoot length of the maize was higher than that of black gram.

\section{Root Length}

The root lengths were noted on $7^{\text {th }}$ day, $14^{\text {th }}, 21^{\text {st }}$ and $28^{\text {th }}$ day. The root length was gradually increased in the above date of harvest. The root length on $28^{\text {th }}$ day analysis was $8.50,11.64,11.84,9.00 \& 10.40 \mathrm{~cm}$ from the control and treated plants of $\mathrm{P}, \mathrm{PB}, \mathrm{R}+\mathrm{PB}$ mixture and RNE (respectively) in black gram \& 9.98,14.20,14.48, 11.30,12.99 cm from the control and treated plants of $\mathrm{P}, \mathrm{PB}, \mathrm{R}+\mathrm{PB}$ and $\mathrm{RNE}$ (respectively) in maize (Table 7).

Table 7. Root Length in $\mathrm{cm}$

\begin{tabular}{|c|c|c|c|c|c|c|c|c|c|}
\hline \multicolumn{2}{|c|}{} & \multicolumn{2}{|c|}{$7^{\text {th }}$ Day } & \multicolumn{2}{c|}{$1^{\text {th }}$ Day } & \multicolumn{2}{c|}{$\mathbf{2 1}^{\text {st }}$ Day } & \multicolumn{2}{c|}{$\mathbf{2 8}^{\text {th }}$ Day } \\
\hline S. No. & Treatment & B & M & B & M & B & M & B & M \\
\hline 1. & C & 6.40 & 8.64 & 8.40 & 9.54 & 8.30 & 9.63 & 8.50 & 9.98 \\
\hline & & $100 \%$ & $100 \%$ & $100 \%$ & $100 \%$ & $100 \%$ & $100 \%$ & $100 \%$ & $100 \%$ \\
\hline 2. & R & 9.40 & 10.60 & 10.12 & 11.70 & 11.35 & 13.20 & 11.64 & 14.20 \\
\hline & & $147 \%$ & $123 \%$ & $120 \%$ & $123 \%$ & $137 \%$ & $137 \%$ & $136 \%$ & $142 \%$ \\
\hline 3. & PB & 9.66 & 10.50 & 10.22 & 11.72 & 11.45 & 13.60 & 11.84 & 14.48 \\
\hline 4. & R+PB mix & 7.00 & 9.50 & 8.49 & 10.50 & 8.70 & 10.80 & 9.00 & 11.30 \\
\hline & & $109 \%$ & $110 \%$ & $101 \%$ & $110 \%$ & $105 \%$ & $112 \%$ & $106 \%$ & $113 \%$ \\
\hline 5. & RNE & 8.60 & 10.00 & 9.60 & 11.00 & 9.80 & 11.99 & 10.40 & 12.99 \\
\hline & & $134 \%$ & $116 \%$ & $114 \%$ & $115 \%$ & $118 \%$ & $125 \%$ & $122 \%$ & $130 \%$ \\
\hline
\end{tabular}

Note; $B=$ Black gram, $M=$ Maize 
This result showed that the root lengths of all the treated plant were increased than that of control in both black gram and maize. The root lengths were moderately increased in all treated plants ranges from $6 \%$ to $39 \%$ in black gram and $13 \%$ to $45 \%$ in maize. It was also noted that the root length of the maize was higher than that of black gram.

\section{Total Chlorophyll}

The total chlorophyll content was noted on $7^{\text {th }}$ day, $14^{\text {th }}, 21^{\text {st }}$ and $28^{\text {th }}$ day. The chlorophyll content was gradually increased in the above period of harvest. However, the total chlorophyll content on $28^{\text {th }}$ day analysis was $0.3195,0.3565,0.3969,0.3295,0.3334 \mathrm{mg}$ from the control and the treated plants of $\mathrm{P}, \mathrm{PB}, \mathrm{R}+\mathrm{PB}$ and $\mathrm{RNE}$ (respectively) in black gram and $0.3089,0.3065,0.2869 \& 0.2887 \mathrm{mg} /$-fwt. from the control and the treated plants of $\mathrm{P}, \mathrm{PB}, \mathrm{R}+\mathrm{PB}$ and $\mathrm{RNE}$ (respectively) in maize (Table 8).

Table 8. Total Chlorophyll Contentent in mg/g FWT

\begin{tabular}{|c|c|c|c|c|c|c|c|c|c|}
\hline \multicolumn{2}{|l|}{} & \multicolumn{2}{|c|}{$7^{\text {th }}$ Day } & \multicolumn{2}{c|}{$1^{\text {th }}$ Day } & \multicolumn{2}{c|}{$2^{\text {st }}$ Day } & \multicolumn{2}{c|}{ 28 $^{\text {th }}$ Day } \\
\hline S. No. & Treatment & B & M & B & M & B & M & B & M \\
\hline 1. & C & 0.0378 & 0.0358 & 0.0622 & 0.0622 & 0.2856 & 0.2392 & 0.3195 & 0.3731 \\
\hline & & $100 \%$ & $100 \%$ & $100 \%$ & $100 \%$ & $100 \%$ & $100 \%$ & $100 \%$ & $100 \%$ \\
\hline 2. & R & 0.0531 & 0.0555 & 0.0777 & 0.1591 & 0.3179 & 0.2751 & 0.3565 & 0.3089 \\
\hline & & $141 \%$ & $155 \%$ & $123 \%$ & $156 \%$ & $111 \%$ & $115 \%$ & $111 \%$ & $113 \%$ \\
\hline 3. & PB & 0.0446 & 0.0447 & 0.0666 & 0.1586 & 0.3131 & 0.2726 & 0.3469 & 0.3065 \\
\hline & & $118 \%$ & $124 \%$ & $107 \%$ & $155 \%$ & $110 \%$ & $113 \%$ & $106 \%$ & $110 \%$ \\
\hline 4. & R+PB mix & 0.0388 & 0.0372 & 0.0640 & 0.0659 & 0.2926 & 0.2492 & 0.3295 & 0.2869 \\
\hline & & $102 \%$ & $103 \%$ & $103 \%$ & $106 \%$ & $104 \%$ & $104 \%$ & $103 \%$ & $105 \%$ \\
\hline 5. & RNE & 0.0400 & 0.0397 & 0.0656 & 0.0675 & 0.0322 & 0.2562 & 0.0334 & 0.2887 \\
\hline & & $106 \%$ & $111 \%$ & $105 \%$ & $109 \%$ & $113 \%$ & $107 \%$ & $104 \%$ & $106 \%$ \\
\hline
\end{tabular}

\section{Note; $B=$ Black gram, $M=$ Maize}

This result showed that the chlorophyll content of all the treated plants was increased than that of the control in both black gram and maize. The total chlorophyll content was moderately increased in all treated plants ranges from 3\% to $11 \%$ black gram and $5 \%$ to $13 \%$ in maize. It was also noted that the total chlorophyll content of the maize was higher than that of black gram.

\section{Leaf Soluble Protein}

The soluble protein content was noted on $7^{\text {th }}$ day, $14^{\text {th }}, 21^{\text {st }}$ and $28^{\text {th }}$ day. The protein content was also gradually increased in the above date of harvest. However, the soluble protein content on $28^{\text {th }}$ day analysis was $6.66,6.69$, 
$6.78,6.74, \& 6.76 \mathrm{mg} / \mathrm{g}$ fwt. the control and treated plants of $\mathrm{P}, \mathrm{PB}, \mathrm{R}+\mathrm{PB}$ mixture and RNE (respectively) in maize (Table 9).

Table 9. Leaf Soluble Protein in mg/Fr.wt

\begin{tabular}{|c|c|c|c|c|c|c|c|c|c|}
\hline \multicolumn{2}{|l|}{} & \multicolumn{2}{|c|}{$7^{\text {th }}$ Day } & \multicolumn{2}{c|}{$\mathbf{1 4}^{\text {th }}$ Day } & \multicolumn{2}{c|}{$\mathbf{2 1}^{\text {st }}$ Day } & \multicolumn{2}{c|}{$\mathbf{2 8}^{\text {th }}$ Day } \\
\hline S. No. & Treatment & B & M & B & M & B & M & B & M \\
\hline 1. & C & 2.40 & 2.10 & 2.88 & 2.30 & 6.12 & 6.43 & 6.66 & 6.54 \\
\hline & & $100 \%$ & $100 \%$ & $100 \%$ & $100 \%$ & $100 \%$ & $100 \%$ & $100 \%$ & $100 \%$ \\
\hline 2. & R & 2.70 & 3.90 & 3.30 & 4.14 & 6.54 & 6.72 & 6.96 & 7.82 \\
\hline & & $112 \%$ & $185 \%$ & $115 \%$ & $180 \%$ & $107 \%$ & $104 \%$ & $105 \%$ & $112 \%$ \\
\hline 3. & PB & 3.00 & 3.00 & 3.42 & 4.04 & 6.43 & 6.90 & 6.78 & 7.14 \\
\hline 4. & R+PB mix & 2.50 & 2.60 & 2.94 & 3.74 & 6.23 & 6.56 & 6.74 & 6.68 \\
\hline & & $125 \%$ & $143 \%$ & $148 \%$ & $176 \%$ & $106 \%$ & $106 \%$ & $102 \%$ & $104 \%$ \\
\hline 5. & RNE & 2.70 & 3.30 & 3.00 & 4.20 & 6.30 & 6.72 & 6.76 & 6.72 \\
\hline & & $112 \%$ & $159 \%$ & $104 \%$ & $183 \%$ & $103 \%$ & $104 \%$ & $102 \%$ & $103 \%$ \\
\hline
\end{tabular}

\section{Note; $\mathbf{B}=$ Black gram, $M=$ Maize}

This result showed that the soluble protein of all the treated plant were increases than that of control in both black gram and maize. The soluble proteins were moderately increased in all the treated plants ranges from $1 \%$ to $5 \%$ in black gram. $2 \%$ to $12 \%$ in maize. It was also noted that the protein of the maize was higher than that of black gram.

\section{Nitrate Reductase Activity}

The nitrate reductive activity was noted on $7^{\text {th }}$ day, $14^{\text {th }}, 21^{\text {st }}$ and $28^{\text {th }}$ day. The NR activity was gradually increased in the above date of harvest. However, the nitrate reductive activities on 28th day analysis were 3.50. 4.00, 4.86, $3.60 \& 3.67 \mathrm{~mol} / \mathrm{no} 2$ form/gfwt/hour from the control and treated plants of P, PB, R+PB and RNE (respectively) in maize (Table 10).

Table 10. NRA activity of moles of $\mathrm{NO}_{2}$ form/g FWT

\begin{tabular}{|c|c|c|c|c|c|c|c|c|c|}
\hline \multicolumn{2}{|c|}{} & \multicolumn{2}{|c|}{$7^{\text {th }}$ Day } & \multicolumn{2}{c|}{$1^{\text {th }}$ Day } & \multicolumn{2}{c|}{$\mathbf{2 1}^{\text {st }}$ Day } & \multicolumn{2}{c|}{$\mathbf{2 8}^{\text {th }}$ Day } \\
\hline S. No. & Treatment & B & M & B & M & B & M & B & M \\
\hline 1. & C & 2.18 & 2.50 & 2.33 & 2.67 & 2.66 & 3.17 & 3.50 & 2.83 \\
\hline & & $100 \%$ & $100 \%$ & $100 \%$ & $100 \%$ & $100 \%$ & $100 \%$ & $100 \%$ & $100 \%$ \\
\hline 2. & R & 2.83 & 3.00 & 2.67 & 3.17 & 3.33 & 3.66 & 4.00 & 4.01 \\
\hline & & $131 \%$ & $120 \%$ & $116 \%$ & $119 \%$ & $125 \%$ & $115 \%$ & $114 \%$ & $141 \%$ \\
\hline
\end{tabular}


Volume 5, Issue 4, Pages 01-15, Oct-Dec 2021

\begin{tabular}{|c|c|c|c|c|c|c|c|c|c|}
\hline 3. & PB & 2.50 & 2.89 & 4.16 & 3.00 & 4.30 & 3.50 & 4.86 & 3.96 \\
\hline & & $116 \%$ & $116 \%$ & $178 \%$ & $112 \%$ & $180 \%$ & $110 \%$ & $139 \%$ & $140 \%$ \\
\hline 4. & R+PB mix & 2.27 & 2.65 & 2.47 & 2.80 & 2.76 & 3.20 & 3.60 & 2.93 \\
\hline & & $105 \%$ & $106 \%$ & $106 \%$ & $105 \%$ & $103 \%$ & $101 \%$ & $103 \%$ & $104 \%$ \\
\hline 5. & RNE & 2.33 & 2.69 & 2.56 & 2.83 & 3.17 & 3.33 & 3.67 & 3.50 \\
\hline & & $108 \%$ & $108 \%$ & $107 \%$ & $109 \%$ & $119 \%$ & $105 \%$ & $105 \%$ & $124 \%$ \\
\hline
\end{tabular}

\section{Note; $B=$ Black gram, $M=$ Maize}

This result showed that the nitrate reductase activities of all the treated plants were increased than that of control in both black gram and maize. The nitrate reductive activity was moderately increase in all the treated plants ranges from $3 \%$ to $14 \%$ in black gram and $4 \%$ to $41 \%$ in maize. It was also noted that the nitrate reductase activity of the maize was higher than that of black gram. The growth parameters (root, shoot length, fresh weight of root and shoot, dry weight of shoot and root) and the biochemical parameters were decreased in the dual infected (R+PB) plants (higher than the control) in both maize and black gram (Table 11, and 12).

Table 11. Interation of Rhizobuim + Phosphobacterium Mixture in Black Gram

\begin{tabular}{|c|c|c|c|}
\hline Parameter & Predicted & Observed & Interation \\
\hline Seed germination & 112 & 105 & Antagonistic \\
\hline Shoot Fresh Weight & 315.30 & 304.00 & Antagonistic \\
\hline Root fresh weight & 147.15 & 120.60 & Antagonistic \\
\hline Shoot dry weight & 39.49 & 29.26 & Antagonistic \\
\hline Root dry weight & 19.47 & 18.30 & Antagonistic \\
\hline Shoot length & 32.26 & 30.56 & Antagonistic \\
\hline Root length & 11.74 & 9.00 & Antagonistic \\
\hline Total chlorophyll & 0.3517 & 0.3295 & Antagonistic \\
\hline Soluble Protein & 6.87 & 6.74 & Antagonistic \\
\hline NRA & 4.43 & 3.60 & Antagonistic \\
\hline
\end{tabular}

Table 12. Interation of Rhizobuim + Phosphobacterium Mixture in Maize

\begin{tabular}{|c|c|c|c|}
\hline Parameter & Predicted & Observed & Interation \\
\hline Seed germination & 112 & 105 & Antagonistic \\
\hline Shoot Fresh Weight & 889.24 & 847.00 & Antagonistic \\
\hline
\end{tabular}


Volume 5, Issue 4, Pages 01-15, Oct-Dec 2021

\begin{tabular}{|c|c|c|c|}
\hline Root fresh weight & 251.15 & 201.80 & Antagonistic \\
\hline Shoot dry weight & 99.78 & 78.34 & Antagonistic \\
\hline Root dry weight & 47.35 & 32.96 & Antagonistic \\
\hline Shoot length & 37.95 & 35.40 & Antagonistic \\
\hline Root length & 14.34 & 11.30 & Antagonistic \\
\hline Total chlorophyll & 0.3077 & 0.2864 & Antagonistic \\
\hline Soluble Protein & 7.48 & 6.68 & Antagonistic \\
\hline NRA & 3.98 & 2.93 & Antagonistic \\
\hline
\end{tabular}

\section{Disscussions}

\section{Seed Germination}

The percentage of seed germination was higher than that of control in all the treated condition of $\mathrm{P}, \mathrm{PB}, \mathrm{R}+\mathrm{PB}$ and RNE (fig-1) it may be due to various growth regulators presents at any time may affect germination and growth rate of plant organ. In addition, synthesis of growth substance depends on the medium composition of raise are fall in concentration of medium. (Thiman 1972). The inoculated bacteria may produce substance such as auxin, gibberellinee and cytokinin as well as plant growth inhibitors. The high percentage of germination may be due to the formation of auxin, gibberellinee and cytokinins and other growth regulators. This may have enhanced the percentage of seed germination than the control.

\section{Plant growth}

In both black gram and maize, the fresh weight dry with of shoot and root, shoot length and root length of the treated plants $(\mathrm{R}, \mathrm{PB}, \mathrm{R}+\mathrm{P}, \mathrm{RNE})$ were increased than the control. It is positively correlated with findings of Alagawadi and A.C. Gaur (1987) In Soybean, Hernandeze and Hill (1983) In Cowpea G. Ghosh (1989) In Summer Moong, Vashimalsi and Subramaniyan (1980) In Legumes, R. Chandra (1991). In Green gram S.K. Kothari and C.S. Sarf (1990) In Mung.

Bhatnagar et al., (1979) In Soybean. Misra and Singh (1967) in Soybean. This may be due to the following reasons. The efficient strains of inoculated rhizobium well established inside the root by forming nodules which fix Nitrogen symbiotically, rhizohium \& phorphobactrium however must become established in the rhizosphere competition with many other microorganisms. They are disturbing the normal biological balance in the root zone. It has been stated that inoculation can be expected to improve plant growth mainly if the bacteria are established and growned in the rhizosphere.

The biofertilizer can improve the bacterial growth and the establishment of a large population of inoculated microorganism. Cooper (1959). The inoculated bio fertilizers may produce substances belonging to auxin, gibberellins cytokinin as well as plant growth inhibitors. This was supported by findings of Lu et al., (1958). 
Microorganism able to form symbiotic association with plant such as vesicular arbuscular mycorrhizae (VAM) and rhizobium legumes have been described to improve plant growth nutrition much more efficiently than free living microorganism. The proportion of various hormones present at any time determines the growth rate of plant.

The improved plant growth nay is dues to interaction of hormones from the both host plants and bacteria in the rhizosphere. Different kinds of unknown substance were also synthesized.

Combined inoculation of rhizobium and phosphobacterium promote growth. It may be due to cumulative effect such as supply of $\mathrm{N}$ and $\mathrm{P}$ to the drop in addition to growth promoting substances produced by the organisms Pareek and Gaur (1973).

The microorganism in the rhizosphere can increase or decrease the absorption of inorganic nutrients by plant roots. These effects depend on the availability of elements and the physical conditions around the roots.

Regarding the biomass accumulation (fresh weight, dry weight, root length, short length) was comparatively higher in the maize that the black gram. This may be due to the individual characters of the plant body by which the maize can synthesis more biomass normally than the black gram.

\section{Biochemical Parameters}

The biochemical parameters such as total chlorophyll content soluble protein content and $\mathrm{N}$ R activity was studied. It was comparatively higher in all the treated planted $(\mathrm{R}, \mathrm{P}, \mathrm{R}+\mathrm{P}, \& \mathrm{RNE})$ than the control in both black gram and maize.

The total chlorophyll content was also high in the treated plants. This is due to the formation of more amounts of nitrate and phosphate formed in the soil by the application of Rhizobium and phospobacterium.

The total chlorophyll content and protein content was also higher in the treated plants than the control in both black gram and maize. It is directly correlated with the growth of the plants. The growth of the plants depends up on the available nutrients phosophorous and nitrate in the soil.

The inoculation of rhizobium and phorphobacterium synthesis more amount of $\mathrm{No}_{4}$ and phosphate from the atmosphere by symbiotically. So that the plants were able to grow well than that of control by absorbing the minerals No4 and Po4 by root system. The increased chlorophyll content is also correlated with the height level of photosynthetic process. High rate of photosynthetic process increases the synthesis of starch. The increased starch content may increase the level up protein content.

The NR activity was also higher in the treated plants $(\mathrm{R}, \mathrm{PB}, \mathrm{R}+\mathrm{P}, \mathrm{RNE})$ than the control in both black gram and maize. This is positively correlated with the finding of Maiti C.C. Das B.N. Chatterjee and K. Sengupta 1988 in green gram and lenti Alagawdi and A.C. Gaur (1988) in chickpea, Sullia (1968) in chick pea.

The NR activity is depending upon the reacting substance NO4 available in the soil. The inoculated biofertilizers enhances the synthesis of nitrate from the atmospheric free nitrogen by symbiotic NZ fixation in the soil. This $\mathrm{NO}_{4}$ is absorbed by the root system of the plant and it will enhance the NR activity in the leaf. Phorphours availability generally enhances symbiotic nitrogen fixation 
In the Rhizohium + Phosphobacterium treated plants the total chlorophyll contents protein content and NR activity was decreased than the other treated plants. (Higher than the control). This may be due to the interaction of growth regulating substance from the bacteria and from the host and also by the formation of growth inhibitor. The growth and multiplication of rhizobium and phosphobacterium will be inhibited by the synthesis of inhibitors. This will directly affect the growth.

The growth parameters (root and shoot length, fresh dry weight of root shoot) and the observed bio chemical parameters were decreased in the dual infected plants $\mathrm{R}+\mathrm{PB}$ mixture (higher than the control) than the other treated plants in both maize and black grams. It shows antagonistic effect in all the observed parameters. It may be due to the combined effects of Rhizobium and phosphobacteria activity in the rhizosphere. Some growth inhibitors may be synthesis by the interaction of microorganism which ma suppresses the growth of the plants.

\section{Summary}

The growth parameters such as the fresh wt, dry wt. of root and shoot, root length was increased in all the treated plants than the control in both black gram and maize. The biochemical parameters such as total chlorophyll content, soluble protein content and NRA activity were also increased than the control in both black gram and maize. This may be due to the formation of hormones such as auxin, gibberellins and cytokines in the inoculated plants. The hormones were enhancing by the inoculation of bio fertilizers in the treated plants. The growth and biochemical parameters were also increased due to the rapid growth of plants by taking more amounts of nitrate and phosphate from the soil. This phosphate and nitrate content was increased in the soil by the action of bio fertilizers by symbiotic fixation process. The overall biomass of maize as a $\mathrm{C}_{4}$ plant and it can fix more amount of $\mathrm{Co}_{2}$ than the black gram.

\section{Declarations}

\section{Source of Funding}

This research did not receive any grant from funding agencies in the public, commercial, or not-for-profit sectors.

\section{Competing Interests Statement}

The authors declare no competing financial, professional and personal interests.

\section{Consent for publication}

Authors declare that they consented for the publication of this research work.

\section{References}

[1] Arnon, D.I., (1949). Copper enzymes in isolated chloroplasts polyphenol oxidase in Beta vulgaris. Plant Physiol., 24, pp.1-15.

[2] O H Lowry, N J Rosebrough, A L Farr, R J Randall, (1951). Protein measurement with the Folin phenol reagent. J Biol Chem, Nov., 193(1), pp. 265-75. 
[3] E G Jaworski, (1971). Nitrate reductase assay in intact plant tissues. Bio. Biophys Res Com., 43(6), pp. 1274-9.

[4] Thiman, (1972). The molecular biology of plant development. the botanical monographs. 18, pp. 271-279.

[5] Gaur, A. C., \& Alagawadi, A. R., (1989). Interaction of nitrogen fixing and bol section. ISCA, Bangalore.

[6] Hernandez, LG., \& G.D. Hill, (1983). Response of chickpea (cicer aarietinum l.) to inoculation and nitrogen fertilizer application. Proceedings Agronomy Society of N.Z. 14, pp. 101-104.

[7] Poi S., C.G.Ghosh, M.C. Kabi, (1989). Response of chickpea (cicer arietinum l.) to combined inoculation with rhizobium, phosphobacteria and mycorrhizal organisms zentralblatt für mikrobiologie. 144(4), pp. 249-253.

[8] Vasimalai, M. P., Subramanian, S., (1980). Response of green gram to irrigation and phosphorus. Madras Agricultural Journal, 67(8), pp. 506-509.

[9] Chandra, R. K., (1991). Basic immunology and its application to nutrition. In Nutrition and Immunology. [Blackburn, G., editor], New York: Academic press.

[10] Kothari, S.K., \& C.S. Saraf, (1991). Response of mungbean (Vigna radiata L.Wilczek) to bacterial seed inoculation and phosphorus application. Ind. J. of plant physiology, 33(4), pp. 327- 332.

[11] Bhatnagar K.B., \& P. P. Hallan, (1979). Effect of perturbed potentials on the stability of liberation points in the restricted problem. Celestial Mechanics, 20, pp. 95-103.

[12] Misra, R.M., \& R. A. Singh, (1967). Three-dimensional formulation of gravitational null fields. II. Journal of Mathematical Physics, 8, pp. 1065.

[13] Cooper Jr. H.H., (1959). A hypothesis concerning the dynamic balance of fresh water and salt water in a coastal aquifer. Journal of Geophysical Research, 65(4), pp. 461-467.

[14] Lu, K.C., C.M. Gilmour, A.C. Zagallo, \& W. B. Bollen, (1958). 'Effects of gibberellic acid on soil micro-organisms. Nature, 181, pp. 189-190.

[15] Pareek, R. P., \& A. C. Gaur ., (1973). Organic acids in the rhizosphere of zea mays and phaseolus aureus plants. Plant and Soil, 39, pp. 441-444.

[16] Shanker Bhat Sullia, (1968). Effect of foliar spray of hormones on the rhizosphere mycoflora of leguminous weeds. Plant and Soil, 29, pp. 292-298. 